\title{
Academic Information System for Student (Case Study: Victory University of Sorong)
}

\author{
Melda Agnes Manuhutu \\ Victory University of Sorong \\ Indonesia
}

\author{
Lulu Jola Uktolseja \\ Victory University of Sorong \\ Indonesia
}

\author{
Sherly Gaspersz \\ Victory University of Sorong \\ Indonesia
}

\begin{abstract}
Educational institutions should be able to use and utilize information technology as a supporter of operational activities in producing accurate information. Victory University is one of higher education institutions that its operational works process is still manual, it is seen with the condition of data process of student academic value which is still processed offline. By this condition, the problem that arises is a complicated process because of the excessive use of time and paper, causing overhead to the students and the University. Therefore, the researcher conducts research with the title, "Academic Information System for Student (Case study: Victory University of Sorong)".
\end{abstract}

\section{General Terms}

Information System

\section{Keywords}

Academic, Information, System, Student

\section{INTRODUCTION}

The rapid development of information technology becomes a big challenge for all parties. Implementation of information system is a form of development information technology. It must be considered in terms of utilization and appropriate safeguards, so the results achieved can be in accordance with the objectives that meet the needs of technology users itself. Information technology is used to process data, including obtaining, organizing, processing, storing and manipulating data in various ways to produce a good quality information. The result of information must be relevant, accurate and timely so that it can be used for every institution, whether public or private, one of which is an educational institution. Educational institutions should be able to use and utilize information technology as a supporter of operational activities in producing accurate information. Victory University is one of higher education institutions that its operational works process is still manual, it is seen with the condition of data process of student academic value which is still processed offline. Any student who wants to see his/her academic grades has to go to the university to print out his/her KHS (study result cards) and value transcript. By this condition, the problem that arises is a complicated process because of the excessive use of time and paper, causing overhead to the students and the University. Therefore, the researcher conducts research with the title, "Academic Information System for Student (Case study: Victory University of Sorong)".

\section{LITERATURE REVIEW}

\subsection{Concept of Information system}

System is a collection or set of elements or variables that are interrelated, interacting, and interdependent with each other to achieve the goal [1]. McFadden, et al. [2] defines information as data that has been processed in such a way as to increase the knowledge of a person using the data. Information is data that has been processed into a meaningful form for the recipient and useful for the current or future time [3]. Information Systems is a system within an organization that brings daily transaction processing needs, supports operations, is managerial and strategic activities of an organization and provides certain outside parties with the necessary reports [4].

\subsection{Academic Information System}

Academic is a field that learns about curriculum or inner learning its function is to increase knowledge in terms of education that can be managed by a school or educational institution [5]. Academic information system is a system that provides information services in the form of data in matters relating to academic data [6].

\subsection{PHP Language}

Ardhana [7] PHP is a server-side programming language that can parse PHP scripts into web scripts so that the client side produces an interesting appearance. It was originally created by Rasmus Lerdorf in 1994, the PHP reference implementation is now produced by The PHP Group. PHP originally stood for Personal Home Page, but it now stands for the recursive acronym PHP: Hypertext Preprocessor. PHP code may be embedded into HTML code, or it can be used in combination with various web template systems, web content management systems, and web frameworks. PHP code is usually processed by a PHP interpreter implemented as a module in the web server or as a Common Gateway Interface (CGI) executable. The web server combines the results of the interpreted and executed PHP code, which may be any type of data, including images, with the generated web page. PHP code may also be executed with a command-line interface (CLI) and can be used to implement standalone graphical applications [8].

\subsection{Database}

Sutarman [9], Database is a set of files that are interconnected and organized or a collection of records that store data and study the relationships between them. Ladjamudin [10], Database is a set of data stores (can be in very large amounts) stored in magnetic disk, optical disk, magnetic drum, or other secondary storage media.

\subsection{MySQL}

Anhar [11], MySQL is a database management system (DBMS) software or DBMS software from many DBMS, such as Oracle, MS SQL, Postagre SQL, etc. Bunafit [12], MySQL is a software or database server program.

\section{METHODOLOGY}

The system development model used in this research is waterfall model. Waterfall model was first known as SDLC model to be used widely in Software Engineering to ensure 
success of the project. In the waterfall approach, the whole process of software development is divided into separate phases. In this Waterfall model, typically, the outcome of one phase acts as the input for the next phase sequentially. The sequential phases in Waterfall model are :

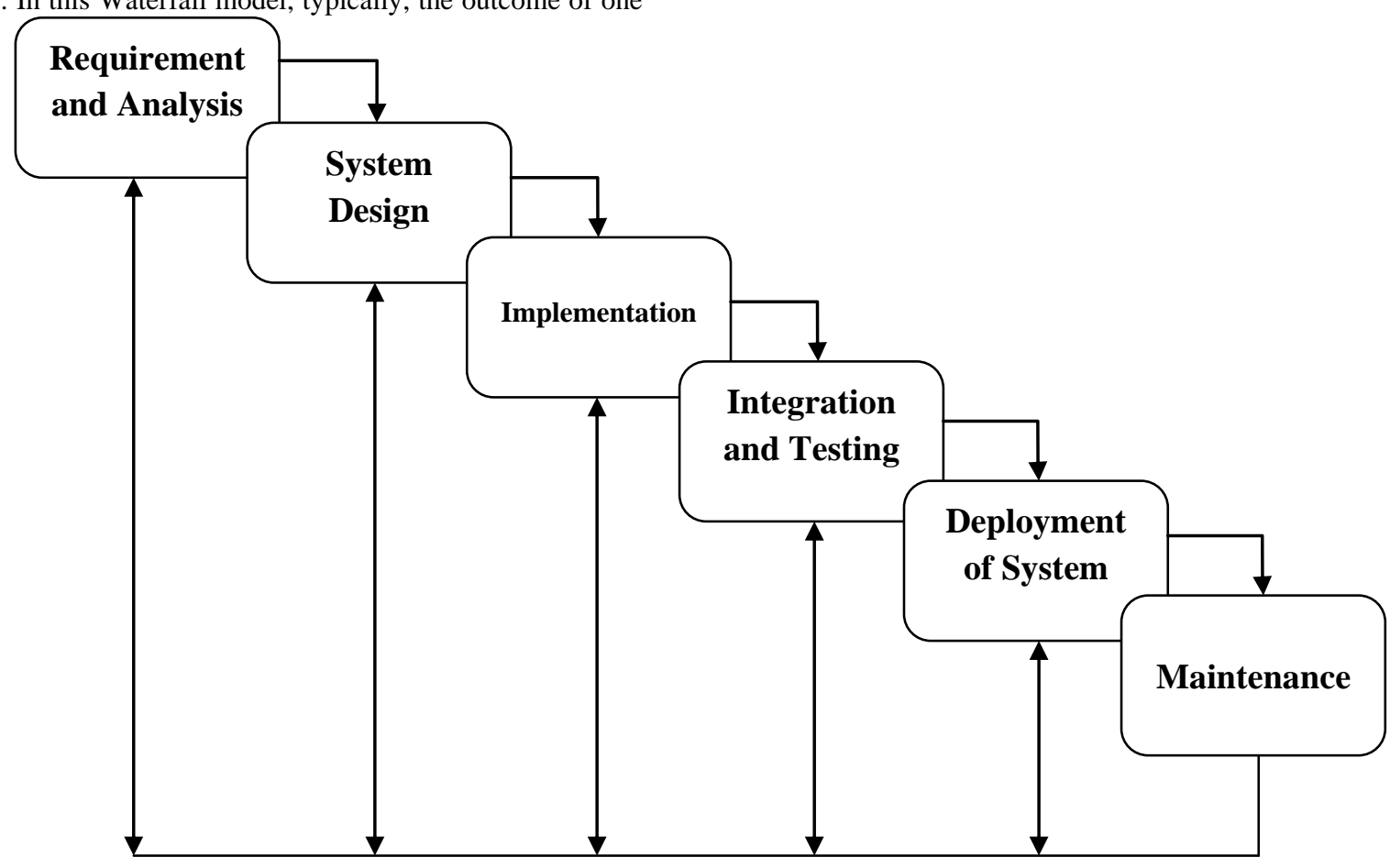

Figure 1: Waterfall Model

1. Requirement and analysis - All possible requirements of the system to be developed are captured in this phase and documented in a requirement specification document.

2. System Design - The requirement specifications from first phase are studied in this phase and the system design is prepared. This system design helps in specifying hardware and system requirements and helps in defining the overall system architecture.

3. Implementation - With inputs from the system design, the system is first developed in small programs called units, which are integrated in the next phase. Each unit is developed and tested for its functionality, which is referred to as Unit Testing. For this implementation system using PHP language and MySQL as Database.

4. Integration and Testing - All the units developed in the implementation phase are integrated into a system after testing of each unit. Post integration the entire system is tested for any faults and failures.

5. Deployment of system - Once the functional and nonfunctional testing is done; the product is deployed in the customer environment or released into the market.
6. Maintenance - There are some issues which come up in the client environment. To fix those issues, patches are released. Also to enhance the product some better versions are released. Maintenance is done to deliver these changes in the customer environment.

All these phases are cascaded to each other in which progress is seen as following steadily downwards (like a waterfall) through the phases. The next phase is started only after the defined set of goals are achieved for previous phase and it is signed off, so the name "Waterfall Model". In this model, phases do not overlap. The following illustration is a representation of the different phases of the Waterfall Model (fig.1).

Method of system design in this research is Unified Modeling Language (UML). Unified Modeling language (UML) is a standardized modeling language enabling developers to specify, visualize, construct and document artifacts of a software system. Thus, UML makes these artifacts scalable, secure and robust in execution. 

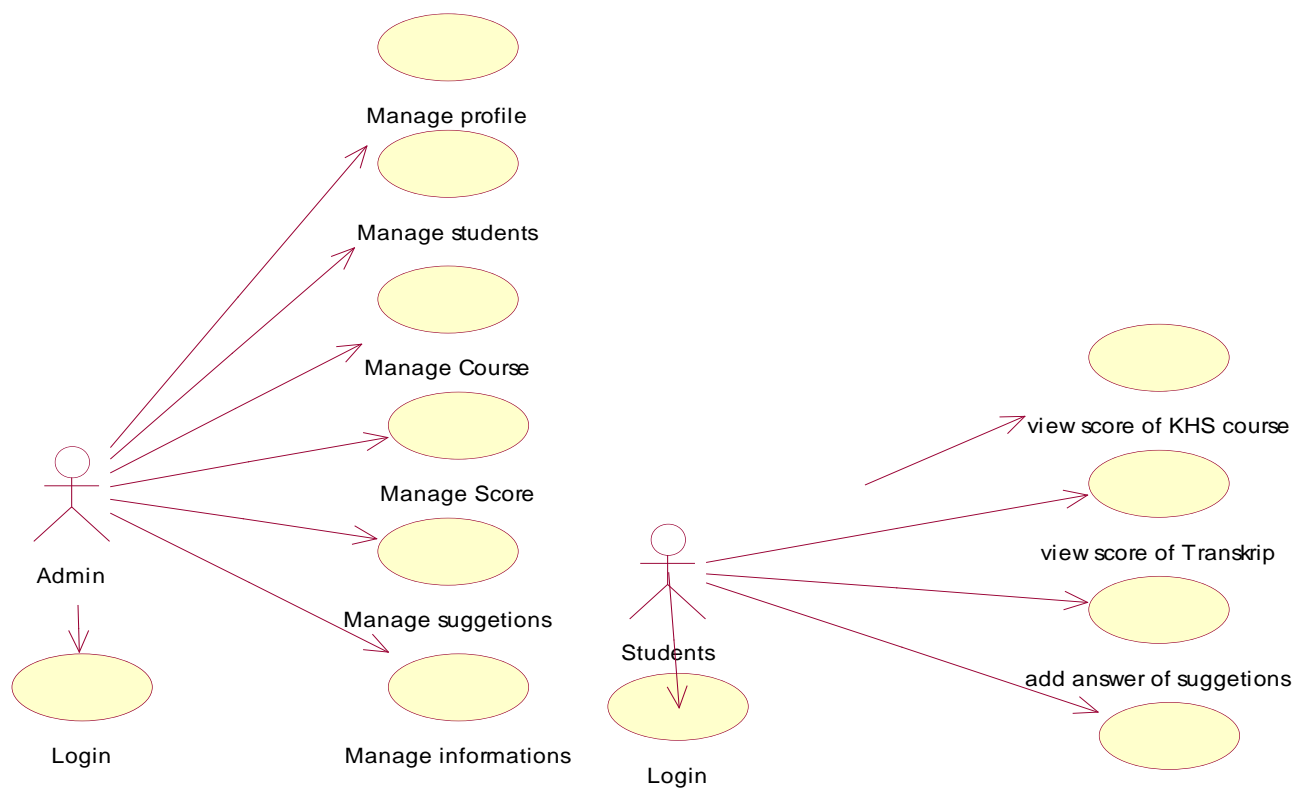

Figure 2: Unified Modelling Language (UML)

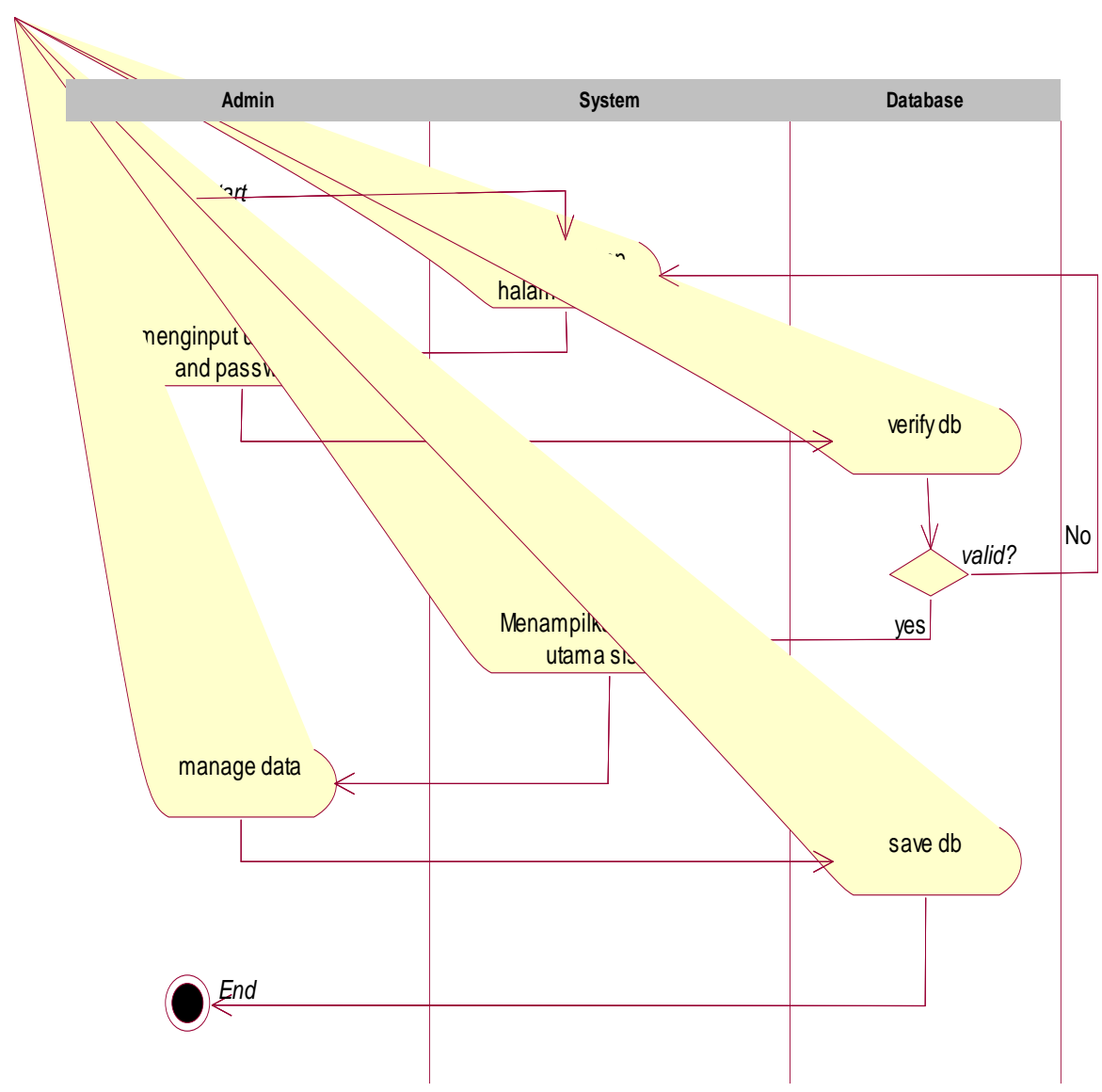

Figure 3: Admin Activity Diagram on SIMAK

Figure 2 describes the use case diagram of the Academic information system (SIMAK) in Victory University, Sorong. In this use case diagram there are 2 actors, they are admin and student. In this use case there are several use cases of each actor, where illustrated that first actor (admin) can manage several data on this SIMAK such as profile admin, manage student, manage course, manage score, manage suggestions, manage information. On the other side, second actor (student) 
can manage several data such as view score of KHS (student result card) and transcript, add answer of suggestions and Figure 3 describes the activity of the first actor (admin) on SIMAK. On the activity diagram, admin first $\log$ in to the system by inputting correct username and password on log in page that is displayed on the system. If admin put wrong username and password he/she will go back to the previous step. If the log in process is successful, the system will display the main page of Academic information system (SIMAK), at the next step admin can process and manage all the data on SIMAK according to the needs of data management. view information.

\section{IMPLEMENTATION}

In the academic information system, there are 2 users: admin and student. Here are the modules of explanation for each user:

\subsection{Admin Module}

Admin is the primary user in this system. The management of academic student data value is done by admin

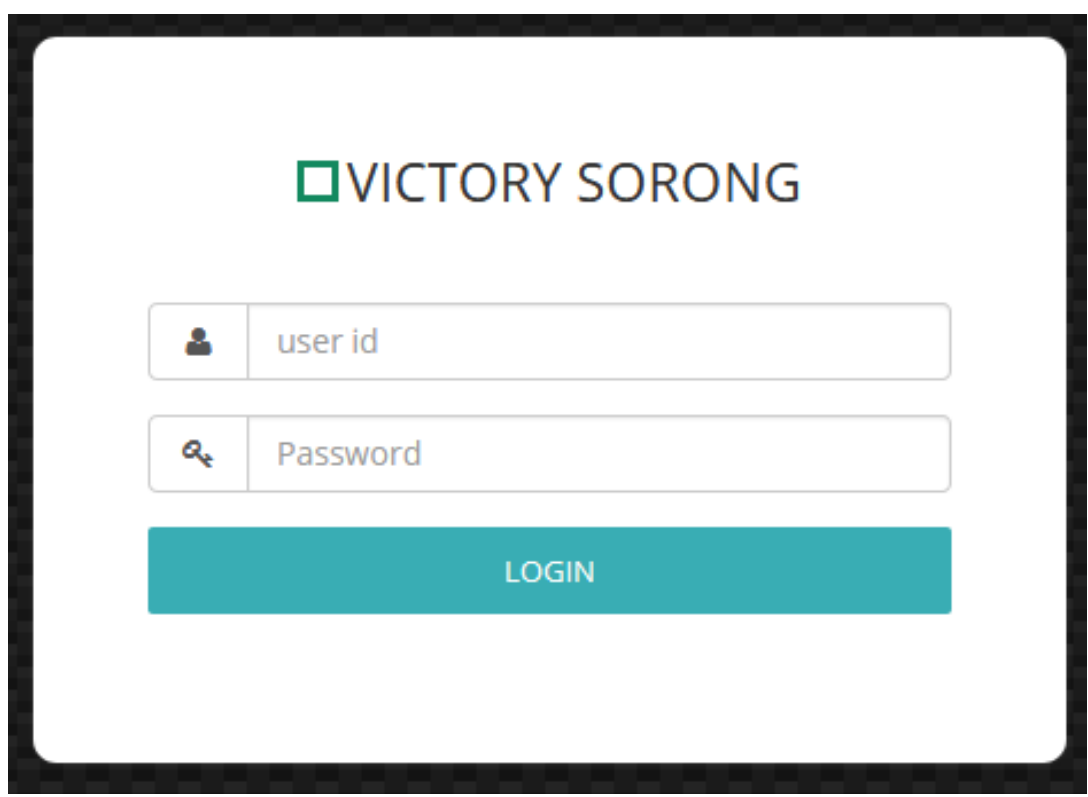

Figure 4: Admin Login Page

Figure 4 is the admin login page of the academic information system. On this page admin must input the username and password as the initial process in accessing the system. The user name and password filled by the admin should be match with the data input in the database. If admin put wrong username and password, system will automatically warning invalid login invoked.

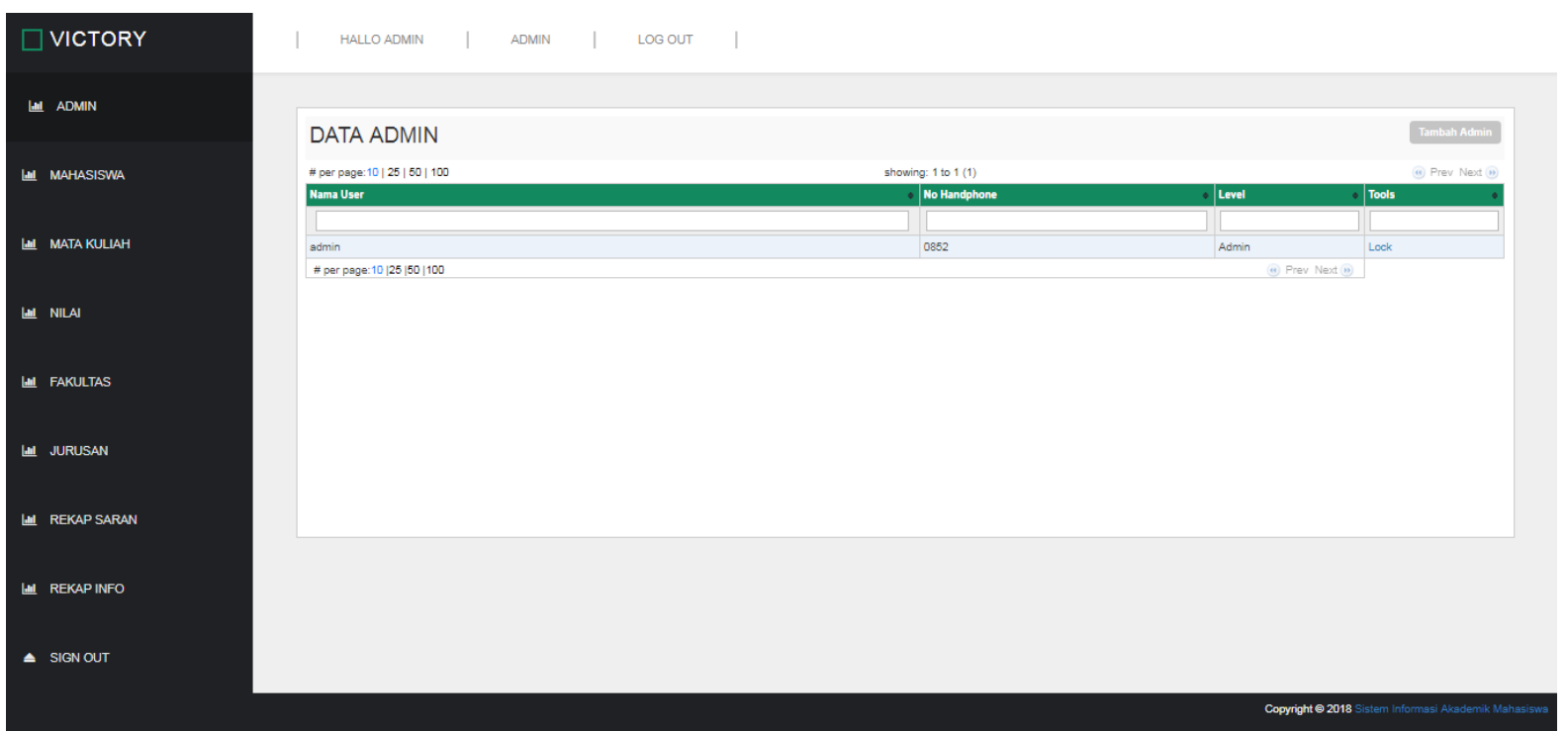

Figure 5: Admin Main Page

Figure 5 is the main page for admin in performing data management on academic information system (SIMAK). There are several menus that are very important in this sytem such as student data management, data course management, score data management, faculty data management, study data program, suggestion data menu, and information data menu. 


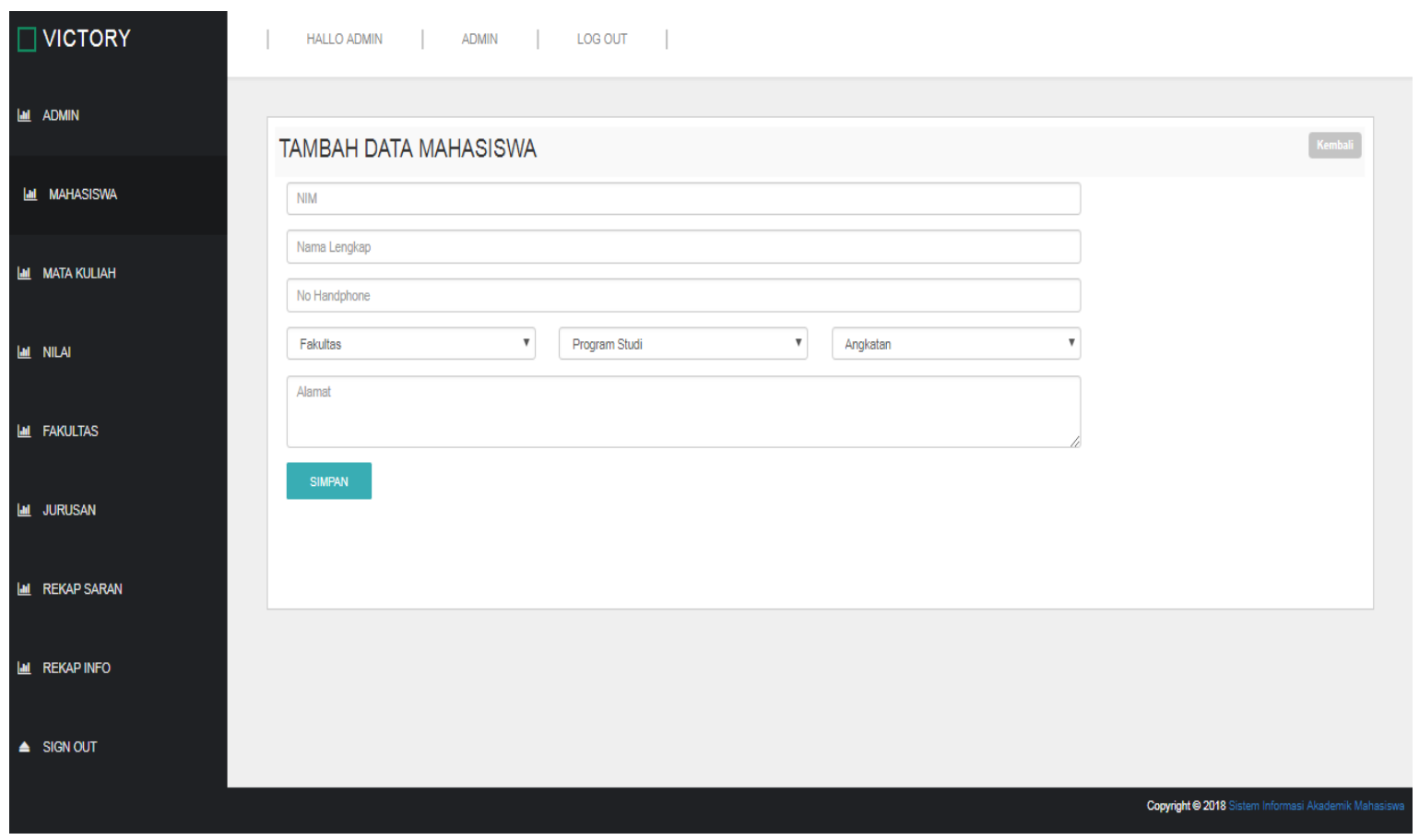

Figure 6: Student Data Management

Figure 6 is the student data management. On this page, admin can add student data of each study program available at Victory University, Sorong.

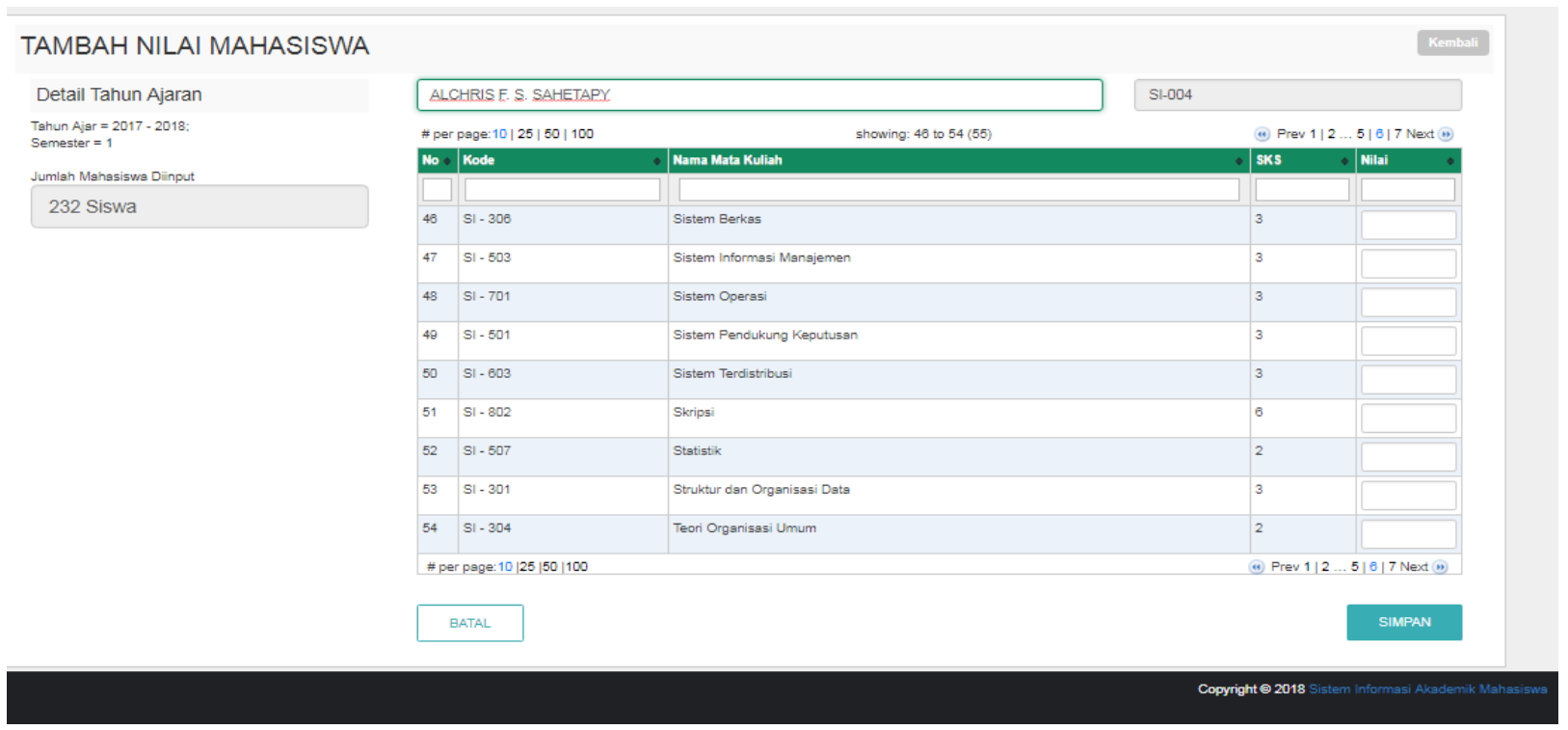

Figure 7: Data Course Management

Figure 7 is the data course management, On this page, admin can manage data value of each study program at Victory University.

\subsection{Students Module}

Student module is a system access page used by students on academic information system (SIMAK). The first step done by the student is the login process (fig.1). After successful login process, student will be able to perform activities in SIMAK system. Where there are some menus in the student panel (fig.2). 


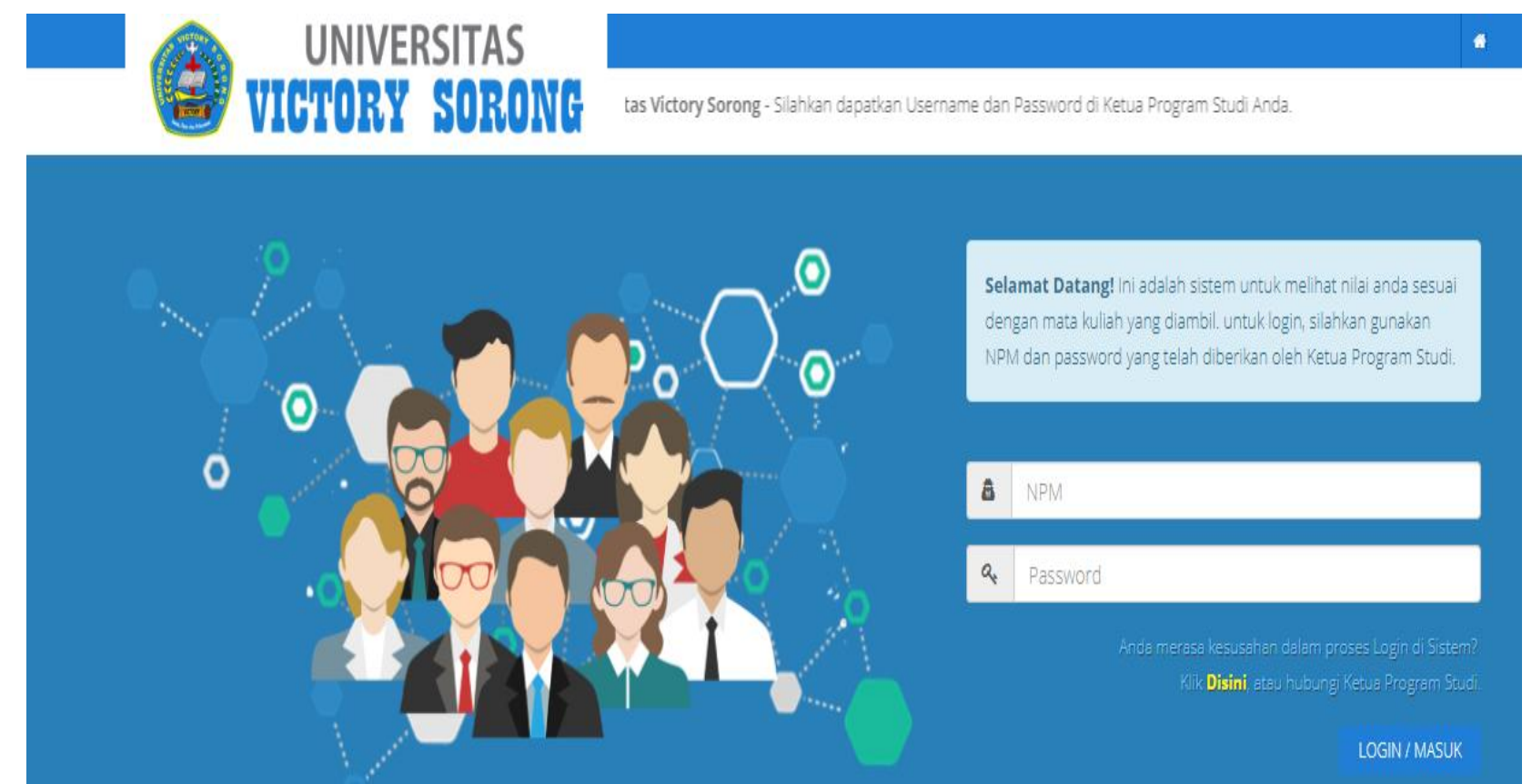

Figure 8: Student Login Page

UNIVERSITAS

VICTORY SORONG

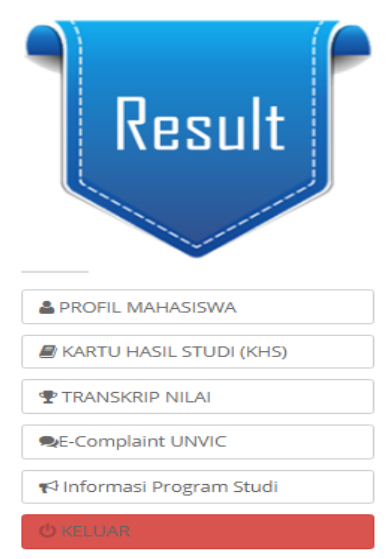

Selamat Datang, AULERIUS LERI BURDAM

Figure 9: Student Page 


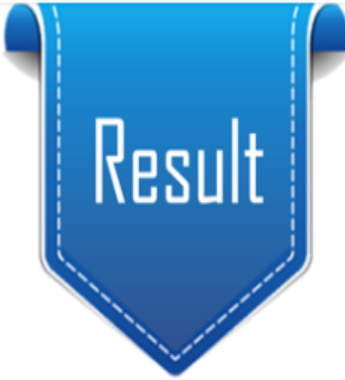

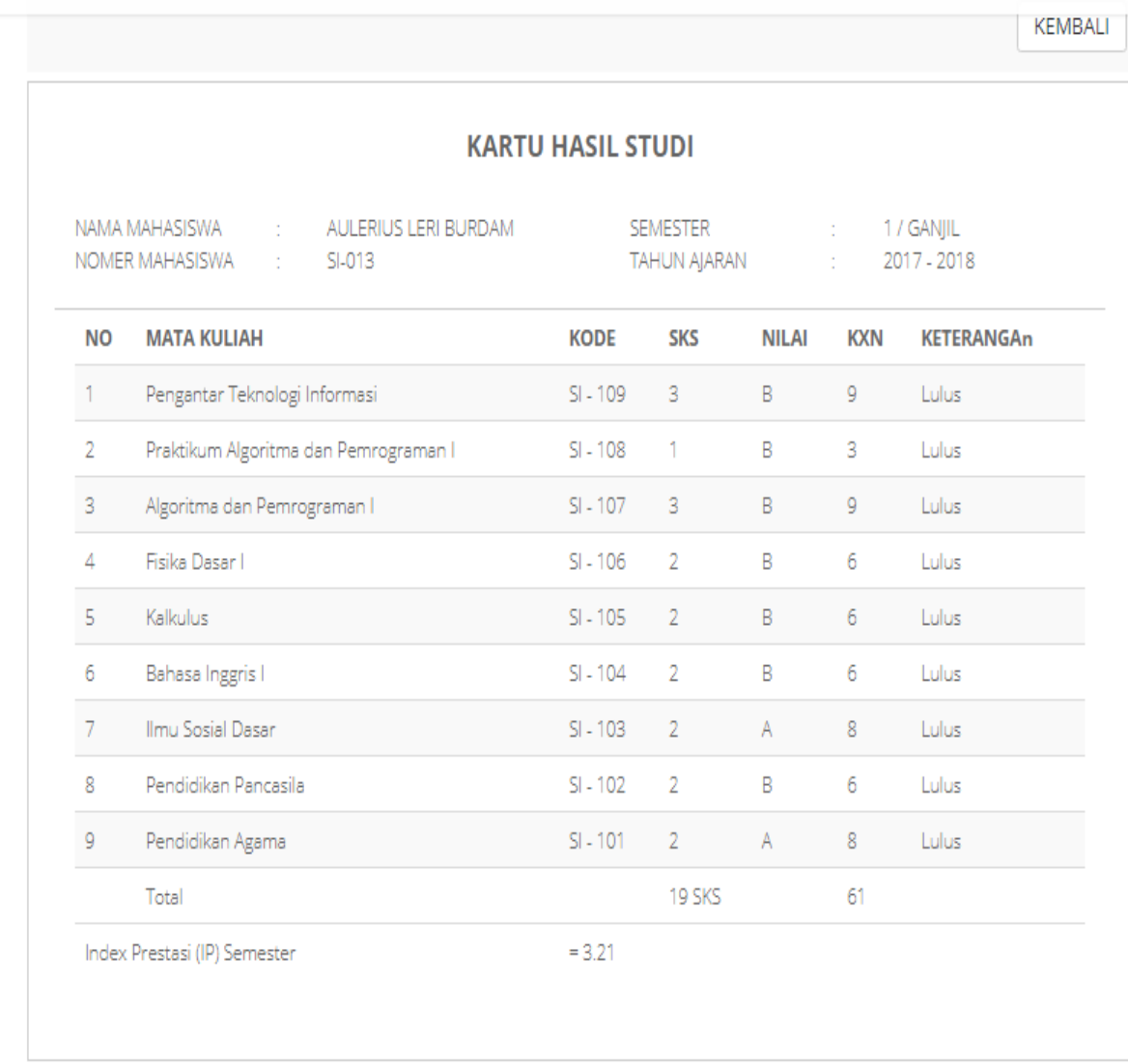

a PROFIL MAHASISWA

G. KARTU HASIL STUDI (KHS)

1 TRANSKRIP NILAI

QE-Complaint UNVIC

A Informasi Program Stud

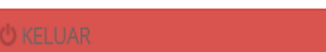

Figure 10: Students Result Card

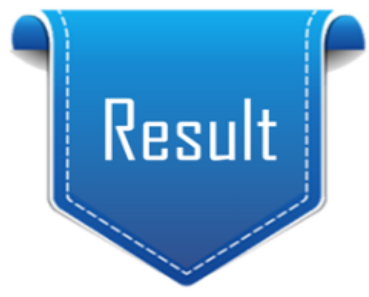

a PROFIL MAHASISWA

G KARTU HASIL STUDI (KHS)

P TRANSKRIP NILAI

E-Complaint UNVIC

NInformasi Program Stud

\section{INFORMASI PROGRAM STUDI}

No Tanggal

Informasi

2018-04:06 00:00:00

Dinfokan kepada mahasiswa akhir utk melunasi biaya adm.KKN dan akan ada pertemuan dengen pihak Rektorat Pada hari Rabu tanggal 11 April 2018 jam 7 malam di Aula kampus Victory. Atas perhatian dan kerjasamanya disampaikan Terimaksh.

2 2018-03-27 00:00:00 Diinfokan bagi Mahasiswa Semester 8 Prodi Sistem Informasi, bahwa Pelaksanaan Seminar Judul

$32018-03.0505: 08: 00$ Tuges Akhir akan dilakukan pada minggu ke dua bulan April. Harap untuk diperhatikan.

Perkuliahan Dimulai tgl 05 Maret 2018

Figure 11: Information Page 

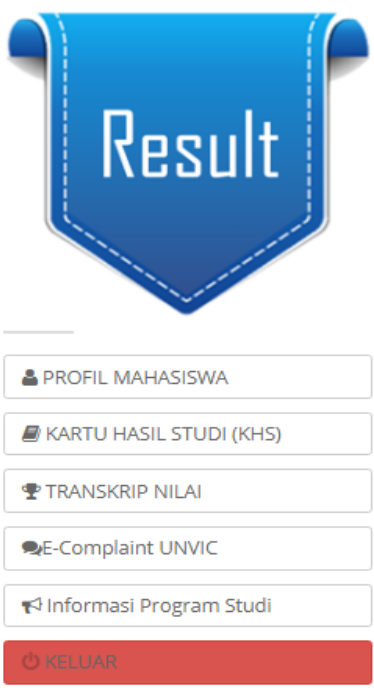

SARAN DAN KRITIK ANDA UNTUK KAMPUS

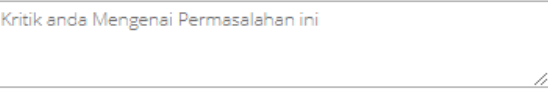

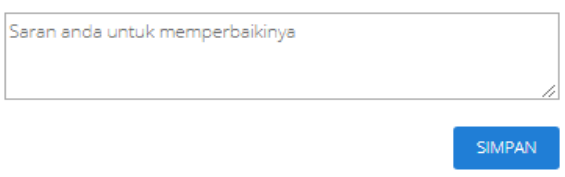

\subsection{System Program Testing}

Academic information system program testing is using blackbox testing method. Black-box testing method was done by giving several inputs to the SIMAK program that later processed suitable with the functional needs to produce the needed output.

\section{CONCLUSION}

In this paper, an academic information system for student is successfully developed, which is much applicable to the University. By this Academic information system can also ease admin and students in seeing the value manually at the office of academic biro, Victory University, Sorong. The future scope of this research is it can be implemented and also for further researcher, they can add any function at algorithm security.

\section{ACKNOWLEDGEMENTS}

The authors are delivering huge thankful to the experts who contributed a lot towards revision and development of this paper.

\section{REFERENCES}

[1] Tohari. 2014. Analisis Serta Perancangan Sistem Informasi Melalui. Pendekatan UML. Yogyakarta: Andi Offset.

[2] McFadden, F. R., Hoffer, J. A., \& Prescott, M. B. 1999. Modern Database Management (Fifth ed.). Reading: Addison-Wesley.
[3] Kadir, A. 2013. Pengenalan Sistem Informasi Edisi Revisi. Yogyakarta: Andi.

[4] Jogiyanto, HM, 2005, "Analisis dan Desain Sistem. Informasi : Pendekatan Terstruktur Teori dan Praktik Aplikasi Bisnis. Yogyakarta: Andi.

[5] Liatmaja, R. 2013. Sistem Informasi Akademik Berbasis Web Pada Lembaga Bimbingan Belajar Be Excellent Pacitan. Indonesian Jurnal On Networking And Security - ISSN : 2302-5700 Vol. 2 No. 2, 59.

[6] Setiyawan, A. 2013. Pembuatan Sistem Informasi Akademik Berbasis Web. Indonesian Journal On Networking And Security - ISSN : 2302-5700, 2. Tohari, H. (2014). astah. Madiun: Andi.

[7] Ardhana, YM., 2012. Pemrograman PHP Codeigniter Black Box, Purwokerto: Jasakom.

[8] "Introduction: What can PHP do?". PHP Manual. Retrieved 2009-03-05.

[9] Sutarman. 2012. Pengantar Teknologi Informasi. Jakarta: Bumi Aksara.

[10] Al-Bahra Bin Ladjamudin. 2013. Analisis dan Desain Sistem Informasi. Yogyakarta: Graha Ilmu.

[11] Anhar. 2010. Panduan Menguasai PHP \& MySQL Secara Otodidak. Mediakita: Jakarta.

[12] Bunafit. 2013. Dasar Pemograman Web PHP - MySQL dengan. Dreamweaver. Yogyakarta : Gava Media 